\title{
Effect of weeding on the growth, yield and yield contributing characters of mungbean (Vigna radiata L.)
}

\author{
R. Akter, M.A. Samad, F. Zaman* and M. S. Islam \\ Department of Agronomy, Bangladesh Agricultural University, Mymensingh-2202, Bangladesh \\ *E-mail: fzamanbau@gmail.com
}

\begin{abstract}
An experiment was conducted at the Agronomy Field Laboratory of Bangladesh Agricultural University, Mymensingh to assess the effect of weeding on growth, yield and yield contributing characters of mungbean (Vigna radiata L.) CV. BINA mung- 4 during October 2011 to February 2012. The experiment was laid out in a randomized complete block design with four replications. The trial comprised seven treatments namely, $T_{1}=$ no weeding, $T_{2}=$ one-stage weeding (Emergence-Flowering), $\mathrm{T}_{3}=$ one-stage weeding (Flowering-Pod setting), $\mathrm{T}_{4}=$ one-stage weeding (Pod settingMaturity), $T_{5}=$ two-stage weeding (Emergence-Flowering and Flowering-Pod setting), $T_{6}=$ two-stage weeding (Flowering-Pod setting and Pod setting-Maturity) and $\mathrm{T}_{7}=$ three-stage weeding (Emergence-Flowering and Flowering-Pod setting and Pod setting-Maturity). The growth parameters such as relative growth rate $\left(0.075 \mathrm{~g} \mathrm{~g}^{-1} \mathrm{day}^{-}\right.$ ${ }^{1}$ ) and net assimilation rate $\left(0.075 \mathrm{~g} \mathrm{~m}^{-2}\right.$ day $\left.^{-1}\right)$ showed the best performance with $\mathrm{T}_{2}$ at one-stage weeding condition (Emergence-Flowering). Three-stage weeding ensured the highest plant height $(58.62 \mathrm{~cm})$ as well as the highest number of branches (4.45) and leaves (10.34) plant $^{-1}$. Dry weight plant ${ }^{-1}(12.38 \mathrm{~g})$ was highest from three stage weeding and the lowest from no weeding treatment. The highest number of pods (22.03) plant ${ }^{-1}$, the longest pod $(5.95 \mathrm{~cm})$, the highest number of seeds (17.07) pod $^{-1}$ and the highest seed yield (1.38 $\mathrm{t} \mathrm{ha}{ }^{-1}$ ) were obtained from three-stage weeding (Emergence-Flowering and Flowering-Pod setting and Pod setting-Maturity) in mungbean. On the other hand, the lowest seed yield was obtained under no weeding condition. The highest seed yield resulted in higher biological yield (4.70 $\mathrm{t} \mathrm{ha}^{-1}$ ) and the highest harvest index (37.15\%) in three-stage weeding and the lowest from no weeding. Number of pods plant ${ }^{-1}$, length of pod, number of seeds pod ${ }^{-1}$ and 1000 -seed weight showed highly significant positive correlations with seed yield. These parameters strongly influenced the growth, yield and yield contributing characters of mungbean (Vigna radiata L.).
\end{abstract}

Keywords: Weeding, Mungbean, Growth, Yield, Correlation

\section{Introduction}

Mungbean (Vigna radiata L.) is an important pulse crop in Bangladesh. In Bangladesh, mungbean ranks third in acreage and production but ranks first in market price. It has good digestibility and flavor. Mungbean contains $51 \%$ carbohydrate, $26 \%$ protein, $10 \%$ moisture, $4 \%$ mineral and $3 \%$ vitamin (Afzal et al., 2008). Mungbean is highly adapted to the agro-climatic conditions of Bangladesh. Though the agroecological conditions of Bangladesh are favorable for mungbean cultivation, its area under cultivation and total production are low in this country (BBS, 2008). In Bangladesh, the average yield of mungbean is $0.69 \mathrm{t} \mathrm{ha}^{-1}$ (BBS, 2011), which is much lower than those of India and other countries of the world.

There are many reasons of lower yield of mungbean. Weed is one of the most important factors responsible for low yield of mungbean. The decrease in mungbean productivity due to weed competition is $45.6 \%$ (Pandey and Mishra, 2003). Mungbean is very competitive against weed and therefore, weed control is essential for mungbean production. Dry weight of weed increased as the duration of weed competition increased in crop (Islam et al., 1989).

Weeds compete with main crop for space, nutrients, water and light. It is also recognized that a low weed population can be beneficial to the crop as it provides food and habitat for a range of beneficial organisms (Bueren et al., 2002). Weed crop competition commences with germination of the crop and continues till its maturity. Several Growth stages of mungbean such as emergence, flowering and pod setting are greatly hampered by weed. Weed infestation of these stages causes low pod setting and ultimately yield reduces. Weeds above critical population thresholds can significantly reduce crop yield and quality. Weed problem is becoming more and more acute. Weeds have been reported to harbor the viruses and act as a primary source of inoculums, which causes high incidence of virus-like symptoms. However, the aim of weed management should be to maintain weed population at a manageable level. Timely control of weeds is essential for high yield in mungbean. Significantly more seed yields by weeding have been reported in mungbean (Hossain et al., 1990; Kumar and Kiron, 1990; Musa et al., 1996). 
Thus, proper weed management is the main concern for maximum yield of mungbean. Though mungbean is cultivated in many parts of our country, very little research work has been done regarding the effect of weeding on growth and yield contributing characters of mungbean. In the light of above background, the present study was designed to investigate the effects of weeding on growth, yield and yield components of mungbean.

\section{Materials and Methods}

The experiment was conducted at the Agronomy Field Laboratory of Bangladesh Agricultural University, Mymensingh during October 2011 to February 2012. The topography of the field was medium high, silt loam in texture and more or less neutral in reaction and moderate drained condition. The selected variety of mungbean in this experiment is BINA mung- 4. There were seven treatments in this experiment (Fig. 1) $: T_{1}=$ no weeding, $T_{2}=$ one-stage weeding (Emergence-Flowering), $T_{3}=$ one-stage weeding (FloweringPod setting), $T_{4}=$ one-stage weeding (Pod setting-Maturity), $T_{5}=$ two-stage weeding (EmergenceFlowering and Flowering-Pod setting), $T_{6}=$ two-stage weeding (Flowering-Pod setting and Pod settingMaturity) and $T_{7}=$ three-stage weeding (Emergence-Flowering, Flowering-Pod setting and Pod settingMaturity). The experiment was laid out in a randomized complete block design with four replications. The whole experimental area was divided into four blocks. Each block was divided into seven unit plots of 4.0 $\mathrm{m} \times 2.5 \mathrm{~m}$ size each. Thus, the total number of unit plots was $28(7 \times 4)$. Seeds of mungbean variety viz. BINA mung-4 were collected from the Bangladesh Institute of Nuclear Agriculture (BINA), Bangladesh Agricultural University, Mymensingh. The experimental field was first opened with a power tiller on 15 October 2011. The experimental field was prepared by four times ploughing and cross ploughing followed by laddering. The weeds and stubble were removed from each plot and the field was leveled properly before sowing.

\begin{tabular}{|c|c|c|c|c|c|}
\hline & Treatments & Emergence & Flowering & Pod setting & Maturity \\
\hline 1 & $\mathrm{~T}_{1}$ (No weeding) & & & & \\
\hline 2 & $\mathrm{~T}_{2}(\mathrm{E}-\mathrm{F})$ & & & & \\
\hline 3 & $\mathrm{~T}_{3}(\mathrm{~F}-\mathrm{P})$ & & & & \\
\hline 4 & $\mathrm{~T}_{4}(\mathrm{P}-\mathrm{M})$ & & & & \\
\hline 5 & $T_{5}(E-F-P)$ & & & & \\
\hline 6 & $\mathrm{~T}_{6}(\mathrm{~F}-\mathrm{P}-\mathrm{M})$ & & & & \\
\hline 7 & $\mathrm{~T}_{7}(\mathrm{E}-\mathrm{F}-\mathrm{P}-\mathrm{M})$ & & & & \\
\hline
\end{tabular}

$\mathrm{E}=$ Emergence, $\mathrm{F}=$ Flowering, $\mathrm{P}=$ Pod setting, $\mathrm{M}=$ Maturity

Fig. 1 Scheme showing developmental phases during which weeding was applied

Each unit plot was uniformly fertilized with urea, triple superphosphate, muriate of potash, gypsum, zinc sulphate and molibdenum at the rate of $40,100,50,70,4$ and $2 \mathrm{~kg} \mathrm{ha}^{-1}$ respectively, as recommended by the Bangladesh Institute of Nuclear Agriculture (BINA, 2011). All fertilizers were applied at the time of final land preparation. Seeds were sown on 20 October 2011 in rows at 2-3 cm depth and row to row distance was $30 \mathrm{~cm}$. Crop management practices such as drainage, plant protection measures were done as per requirement and weeding was done as per treatment. Data on growth attributes and morphological parameters were collected at 40,50,60 DAS and at harvest. At physiological maturity ten plants plot ${ }^{-1}$ 
were selected randomly, sundried and growth parameters viz. plant height, number of branches plant ${ }^{-1}$, number of leaves plant ${ }^{-1}$, crop growth rate (CGR), relative growth rate (RGR), net assimilation rate (NAR); yield and yield contributing characters viz. number of pods plant ${ }^{-1}$, pod length $(\mathrm{cm})$, weight of seeds pod ${ }^{-1}$ $(\mathrm{g}), 1000$-seed weight $(\mathrm{g})$, seed yield $\left(\mathrm{g} \mathrm{plant}^{-1}\right)$, seed yield $\left(\mathrm{t} \mathrm{ha} \mathrm{f}^{-1}\right)$, stover yield $\left(\mathrm{g}\right.$ plant $\left.{ }^{-1}\right)$, stover yield $\left(\mathrm{t} \mathrm{ha}{ }^{-1}\right)$, biological yield $\left(\mathrm{t} \mathrm{ha}{ }^{-1}\right)$, harvest Index $(\mathrm{HI})$ were recorded.

Crop growth rate is the increase in the plant dry matter production per unit of time per unit of ground area (Hunt, 1978). It was calculated by using the following formula:

$$
\text { CGR }=\frac{w_{2}-w_{1}}{T_{2}-T_{1}} g m^{-2} d^{-1}
$$

Where, $W_{1}=$ Total dry weight at time $\left(T_{1}\right)$ and $W_{2}=$ Total dry weight at time $\left(T_{2}\right)$

Relative growth rate is the rate of DM production per unit of time. It was calculated by using the following formula:

$$
R G R=\frac{\ln w_{2}-\ln w_{1}}{T_{2}-T_{1}} g^{-1} \text { day }^{-1}
$$

Where, $W_{2}$ and $W_{1}$ are the DM at the time $T_{2}$ and $T_{1}$, respectively and $I n$ is the natural logarithm. Net assimilation rate is the rate of DM production per unit of leaf area per unit of time. It was calculated by using the following formula:

$$
\mathrm{NAR}=\frac{\mathrm{w}_{2}-\mathrm{w}_{1}}{\mathrm{~T}_{2}-\mathrm{T}_{1}} \times \frac{\operatorname{lnLA} \mathrm{A}_{2}-\operatorname{lnLA} \mathrm{A}_{1}}{\mathrm{LA}_{2}} \mathrm{~g} \mathrm{~m}^{-2} \mathrm{day}^{-1}
$$

Where, $W_{2}$ and $W_{1}$ are the $D M$ at the time $T_{2}$ and $T_{1}$, respectively. $L A_{2}$ and $L A_{1}$ are leaf area at the time $T_{2}$ and $T_{1}$, respectively. NAR ranges between -1 to $+5.5 \mathrm{~g} \mathrm{~m}^{-2}$ day $^{-1}$.

Collected data were analyzed statistically using MSTAT-C programme and the means were compared by Duncan's Multiple Range Test (DMRT) at $5 \%$ level of probability (Gomez and Gomez, 1984). Correlation coefficient ( $r$ ) was calculated among different variables and correlation matrix was also prepared to find out the relationship among variable to weeding. Regression co-efficient or percent variation accounted $\left(R^{2}\right)$ was also measured.

\section{Results and Discussion}

\section{Growth parameters}

Plant height was significantly affected by weeding at the all sampling days (40 DAS, 50 DAS, 60 DAS and at harvest) (Table 1). At 40 DAS the tallest plant height $(25.31 \mathrm{~cm})$ was obtained from $T_{7}$ where crops received three times weeding from Emergence to Maturity and shortest plant height $(18.36 \mathrm{~cm})$ was obtained from $T_{4}$ where crop received one time weeding from Pod setting to Maturity. At 50 DAS tallest plant height $(30.52 \mathrm{~cm})$ was obtained from $\mathrm{T}_{7}$ where crop received three times weeding from Emergence to Maturity and shortest plant height $(19.54 \mathrm{~cm})$ was obtained from no weeding treatment. At 60 DAS tallest plant height $(40.90 \mathrm{~cm})$ was obtained from $\mathrm{T}_{3}$ where crop received one time weeding from flowering to pod setting and shortest plant height $(31.94 \mathrm{~cm})$ was obtained from no weeding treatment. At harvest tallest plant height $(59.17 \mathrm{~cm})$ was obtained from $\mathrm{T}_{3}$ and shortest plant height $(36.68 \mathrm{~cm})$ was obtained from no weeding treatment. These results indicate that plant height increased with the increase in the number of stage of weeding. Decreased plant height in no weeding condition might be due to inhibition of cell division or cell enlargement. 
Number of branches plant ${ }^{-1}$ significantly differed at 40 DAS, 50 DAS, 60 DAS and at harvest (Table 1). At 40 DAS, the highest number of branches plant ${ }^{-1}(1.10)$ was observed from $T_{7}$ where crop received three times weeding from Emergence to Maturity and the lowest number of branches plant ${ }^{-1}(0.83)$ was recorded with no weeding treatment. Similarly, at 50 DAS, 60 DAS and at harvest, the highest number of branches plant $^{-1}$ (1.41), (2.85) and (4.45) was observed from three times weeding from Emergence to Maturity $\left(T_{7}\right)$ and the lowest number of branches plant ${ }^{-1}$ was observed from no weeding treatment. The results revealed that weeding had direct effect to increase the number of branches. With decreasing weed population, number of branches plant ${ }^{-1}$ increased in mungbean, because of higher absorption of nutrient and water from soil. As a result, activity of cell increased. This favoured more vegetative growth and produced higher number of branches in mungbean plant.

Table 1. Effect of weeding on plant height $(\mathrm{cm})$ and no. of branches plant ${ }^{-1}$ of mungbean

\begin{tabular}{|c|c|c|c|c|c|c|c|c|}
\hline Treatment & \multicolumn{4}{|c|}{ Plant height $(\mathrm{cm})$} & \multicolumn{4}{c|}{ Branches plant $^{-1}$ (no.) } \\
\hline & 40 DAS & 50 DAS & 60 DAS & At harvest & 40 DAS & 50 DAS & 60 DAS & At harvest \\
\hline $\mathrm{T}_{1}$ & $22.30 \mathrm{bc}$ & $19.54 \mathrm{c}$ & $31.94 \mathrm{c}$ & $36.68 \mathrm{~d}$ & $0.83 \mathrm{c}$ & $1.14 \mathrm{~d}$ & $1.41 \mathrm{e}$ & $2.01 \mathrm{~d}$ \\
\hline $\mathrm{T}_{2}$ & $21.17 \mathrm{c}$ & $24.73 \mathrm{~b}$ & $39.24 \mathrm{a}$ & $53.46 \mathrm{~b}$ & $1.05 \mathrm{~b}$ & $1.23 \mathrm{c}$ & $2.31 \mathrm{~d}$ & $3.88 \mathrm{c}$ \\
\hline $\mathrm{T}_{3}$ & $22.83 \mathrm{~b}$ & $24.24 \mathrm{~b}$ & $40.90 \mathrm{a}$ & $59.17 \mathrm{a}$ & $1.03 \mathrm{ab}$ & $1.28 \mathrm{bc}$ & $2.54 \mathrm{~b}$ & $4.21 \mathrm{~b}$ \\
\hline $\mathrm{T}_{4}$ & $18.36 \mathrm{~d}$ & $20.72 \mathrm{c}$ & $34.15 \mathrm{bc}$ & $36.76 \mathrm{~d}$ & $1.06 \mathrm{~b}$ & $1.37 \mathrm{ab}$ & $2.37 \mathrm{~cd}$ & $4.26 \mathrm{ab}$ \\
\hline $\mathrm{T}_{5}$ & $18.93 \mathrm{~d}$ & $24.43 \mathrm{~b}$ & $32.27 \mathrm{c}$ & $47.08 \mathrm{c}$ & $1.02 \mathrm{~b}$ & $1.34 \mathrm{ab}$ & $2.51 \mathrm{bc}$ & $4.15 \mathrm{~b}$ \\
\hline $\mathrm{T}_{6}$ & $17.98 \mathrm{~d}$ & $21.05 \mathrm{c}$ & $35.60 \mathrm{~b}$ & $37.75 \mathrm{~d}$ & $1.03 \mathrm{ab}$ & $1.33 \mathrm{ab}$ & $2.60 \mathrm{~b}$ & $4.14 \mathrm{~b}$ \\
\hline $\mathrm{T}_{7}$ & $25.31 \mathrm{a}$ & $30.52 \mathrm{a}$ & $40.79 \mathrm{a}$ & $58.62 \mathrm{a}$ & $1.10 \mathrm{a}$ & $1.41 \mathrm{a}$ & $2.85 \mathrm{a}$ & $4.45 \mathrm{a}$ \\
\hline $\mathrm{CV}(\%)$ & 4.60 & 5.28 & 4.51 & 4.05 & 9.26 & 4.49 & 4.41 & 10.36 \\
\hline Level of sig. & $\star \star$ & $\star \star$ & $\star \star$ & $\star \star$ & $\star$ & $\star *$ & $* *$ & $*$ \\
\hline
\end{tabular}

In a column, figures with similar letter (s) or without letter do not differ significantly (as per DMRT) at $5 \%$ level of probability, ${ }^{*}=$ Significant at $5 \%$ level of probability, ${ }^{* *}=$ Significant at $1 \%$ level of probability.

Number of leaves plant ${ }^{-1}$ varied significantly by weeding at 40 DAS, 50 DAS, 60 DAS and at harvest (Table 2). Maximum number of leaves plant ${ }^{-1}$ at 40 DAS, 50 DAS, 60 DAS and at harvest were obtained from three times weeding from Emergence to Maturity $\left(T_{7}\right)$ and minimum number of leaves plant $^{-1}$ was obtained from no weeding treatment at 40 DAS, 50 DAS, 60 DAS and at harvest. So, weeding had a direct and positive effect on the number of leaves plant ${ }^{-1}$. Due to increase in weeding level, plant received more light and activity of vascular tissue increased. Ultimately number of leaves plant ${ }^{-1}$ increased.

The influence of weeding on dry weight plant ${ }^{-1}$ was found significant at 40 DAS, 50 DAS, 60 DAS and at harvest (Table 2). The highest dry weight plant $^{-1}(0.79 \mathrm{~g}),(8.14 \mathrm{~g}),(12.38 \mathrm{~g}),(17.95 \mathrm{~g})$ were obtained from $\mathrm{T}_{7}$ at three times weeding (E-M) condition and the lowest amount of dry weights plant ${ }^{-1}(0.24 \mathrm{~g}),(4.13 \mathrm{~g})$, $(6.36 \mathrm{~g})$ and $(8.50 \mathrm{~g})$ were obtained from the no weeding treatment at all sampling days. It was observed that increase in level of weeding increased plant dry weight and the decreased level of weeding reduced the plant dry weight. This indicates that weeding had a direct effect on dry weight of plant. Accumulation of lower dry weights for control treatment might be due to lack of internal nutrient of plant, which caused reduction in both cell division and cell elongation and reduced carbohydrate synthesis and hence the growth was reduced.

Crop growth rate (CGR) varied significantly under different weeding condition (Table 3). At 40-50 DAS, the highest crop growth rate (0.74) was found at $T_{7}$ where crop received three-stage weeding from emergence to maturity. The lowest CGR (0.39) was recorded from no weeding condition $\left(T_{1}\right)$ and the CGR from $T_{2}$ and $T_{5}$ were found similar result. At 50-60 DAS the highest CGR (0.58) was recorded from $T_{2}$ and the lowest (0.22) from $T_{1} .60$ DAS to at maturity the highest CGR (0.61) was recorded from $T_{6}$ and the minimum (0.21) was found from $T_{1}$. 
Table 2. Effect of weeding on number of leaves plant ${ }^{-1}$ and dry weight plant ${ }^{-1}$ of mungbean

\begin{tabular}{|c|c|c|c|c|c|c|c|c|}
\hline Treatment & \multicolumn{4}{|c|}{ Leaves plant $^{-1}(\mathrm{no})}$. & \multicolumn{4}{c|}{ Dry wt. plant $^{-1}(\mathrm{~g})$} \\
\hline & 40 DAS & 50 DAS & 60 DAS & At harvest & 40 DAS & 50 DAS & 60 DAS & At harvest \\
\hline $\mathrm{T}_{1}$ & $3.01 \mathrm{c}$ & $3.75 \mathrm{c}$ & $5.25 \mathrm{c}$ & $8.00 \mathrm{c}$ & $0.24 \mathrm{~d}$ & $4.13 \mathrm{f}$ & $6.36 \mathrm{f}$ & $8.50 \mathrm{~d}$ \\
\hline $\mathrm{T}_{2}$ & $4.25 \mathrm{ab}$ & $7.15 \mathrm{~b}$ & $9.46 \mathrm{~b}$ & $11.82 \mathrm{~b}$ & $0.34 \mathrm{~d}$ & $5.98 \mathrm{~d}$ & $12.21 \mathrm{ab}$ & $17.39 \mathrm{a}$ \\
\hline $\mathrm{T}_{3}$ & $3.70 \mathrm{~b}$ & $7.15 \mathrm{~b}$ & $9.30 \mathrm{~b}$ & $11.42 \mathrm{~b}$ & $0.50 \mathrm{c}$ & $6.51 \mathrm{c}$ & $11.81 \mathrm{bc}$ & $16.37 \mathrm{~b}$ \\
\hline $\mathrm{T}_{4}$ & $3.65 \mathrm{~b}$ & $7.05 \mathrm{~b}$ & $9.40 \mathrm{~b}$ & $11.21 \mathrm{~b}$ & $0.49 \mathrm{c}$ & $5.53 \mathrm{e}$ & $11.00 \mathrm{e}$ & $15.17 \mathrm{c}$ \\
\hline $\mathrm{T}_{5}$ & $3.68 \mathrm{~b}$ & $7.00 \mathrm{~b}$ & $9.24 \mathrm{~b}$ & $11.85 \mathrm{~b}$ & $0.62 \mathrm{bc}$ & $6.20 \mathrm{~cd}$ & $11.48 \mathrm{~cd}$ & $16.67 \mathrm{~b}$ \\
\hline $\mathrm{T}_{6}$ & $3.73 \mathrm{~b}$ & $7.10 \mathrm{~b}$ & $9.06 \mathrm{~b}$ & $12.14 \mathrm{ab}$ & $0.72 \mathrm{ab}$ & $7.34 \mathrm{~b}$ & $11.30 \mathrm{de}$ & $16.36 \mathrm{~b}$ \\
\hline $\mathrm{T}_{7}$ & $4.60 \mathrm{a}$ & $8.28 \mathrm{a}$ & $10.34 \mathrm{a}$ & $13.96 \mathrm{a}$ & $0.79 \mathrm{a}$ & $8.14 \mathrm{a}$ & $12.38 \mathrm{a}$ & $17.95 \mathrm{a}$ \\
\hline $\mathrm{CV}(\%)$ & 8.37 & 4.09 & 5.80 & 2.51 & 2.43 & 2.76 & 4.25 & 7.86 \\
\hline Level of sig. & $\star \star$ & $\star *$ & $\star \star$ & $\star *$ & $\star *$ & $\star *$ & $*$ & $*$ \\
\hline
\end{tabular}

In a column, figures with similar letter (s) or without letter do not differ significantly (as per DMRT) at 5\% level of probability, ${ }^{* *}=$ Significant at $1 \%$ level of probability.

Table 3. Effect of weeding on crop growth rate (CGR), relative growth rate (RGR) and net assimilation rate (NAR) of mungbean

\begin{tabular}{|c|c|c|c|c|c|c|c|c|c|}
\hline \multirow[b]{2}{*}{ Treatment } & \multicolumn{3}{|c|}{ CGR } & \multicolumn{3}{|c|}{ RGR } & \multicolumn{3}{|c|}{ NAR } \\
\hline & $\begin{array}{c}40-50 \\
\text { DAS }\end{array}$ & $\begin{array}{c}50-60 \\
\text { DAS }\end{array}$ & $\begin{array}{c}60 \text { DAS to } \\
\text { Maturity }\end{array}$ & 40-50 DAS & $50-60$ DAS & $\begin{array}{c}60 \text { DAS to } \\
\text { Maturity }\end{array}$ & $\begin{array}{c}40-50 \\
\text { DAS }\end{array}$ & 50-60 DAS & $\begin{array}{c}60 \text { DAS to } \\
\text { Maturity }\end{array}$ \\
\hline T1 & $0.39 \mathrm{e}$ & $0.22 \mathrm{C}$ & $0.21 \mathrm{e}$ & $0.047 \mathrm{c}$ & $0.004 c$ & $0.003 c$ & $0.047 \mathrm{c}$ & $0.004 \mathrm{C}$ & $0.003 \mathrm{c}$ \\
\hline T2 & $0.56 \mathrm{c}$ & $0.58 a$ & $0.45 \mathrm{~cd}$ & $0.075 a$ & $0.018 a$ & $0.007 \mathrm{~b}$ & $0.075 a$ & $0.018 a$ & $0.007 \mathrm{~b}$ \\
\hline T3 & $0.60 \mathrm{c}$ & $0.57 a$ & $0.42 d$ & $0.057 \mathrm{bc}$ & $0.013 b$ & $0.004 c$ & $0.057 \mathrm{bc}$ & $0.013 b$ & $0.004 c$ \\
\hline $\mathrm{T} 4$ & $0.50 \mathrm{~d}$ & $0.55 a$ & $0.42 d$ & $0.058 \mathrm{~b}$ & $0.018 a$ & $0.006 \mathrm{~b}$ & $0.058 \mathrm{~b}$ & $0.018 a$ & $0.006 \mathrm{~b}$ \\
\hline T5 & $0.56 c$ & $0.53 a$ & $0.52 \mathrm{bc}$ & $0.072 a$ & $0.018 a$ & $0.011 \mathrm{a}$ & $0.072 a$ & $0.018 \mathrm{a}$ & $0.011 a$ \\
\hline T6 & $0.66 \mathrm{~b}$ & $0.40 \mathrm{~b}$ & $0.61 a$ & $0.054 b c$ & $0.006 c$ & $0.009 a$ & $0.054 \mathrm{bc}$ & $0.006 \mathrm{c}$ & $0.009 a$ \\
\hline $\mathrm{T7}$ & $0.74 a$ & $0.42 \mathrm{~b}$ & $0.56 a b$ & $0.054 b c$ & $0.006 \mathrm{c}$ & $0.007 \mathrm{~b}$ & $0.054 \mathrm{bc}$ & $0.006 \mathrm{c}$ & $0.007 \mathrm{~b}$ \\
\hline CV (\%) & 11.95 & 7.08 & 7.71 & 24.96 & 2.37 & 2.75 & 24.96 & 2.37 & 2.75 \\
\hline $\begin{array}{c}\text { Level of } \\
\text { significance }\end{array}$ & ** & ** & ** & ** & ** & ** & ** & ** & ** \\
\hline
\end{tabular}

In a column, figures with similar letter (s) or without letter do not differ significantly (as per DMRT) at $5 \%$ level of probability

$* *=$ Significant at $1 \%$ level of probability

Relative growth rate (RGR) varied significantly under different weeding condition (Table 3). At 40-50 DAS, the highest relative growth rate (0.075) was found from $T_{2}$. The lowest RGR (0.047) was recorded from $T_{5} . T_{6}, T_{7}$ showed similar result. At 60 DAS to Maturity, the highest RGR (0.011) was recorded from $T_{5}$ and the minimum (0.003) was found from $T_{1}$. These results showed that RGR decreased with increasing crop age.

Net assimilation rate (NAR) influenced significantly by weeding (Table 3). At 40-50 DAS, the highest NAR (0.075) was recorded from $T_{2}$ and the lowest (0.047) NAR from $T_{1}$. Similar results were found from $T_{6}$ and $T_{7}$. At 50-60 DAS, the highest NAR (0.018) was obtained from $T_{5}$, which were statistically identical at $T_{2}$ and $T_{4}$. The lowest (0.004) from $T_{1}$ at no weeding treatment. At 60 DAS to Maturity the highest NAR (0.011) was found from $T_{5}$ and the lowest (0.003) from $T_{1} . T_{2}$ and $T_{7}$ showed similar results. The results indicated that NAR decreased with increasing crop age and NAR was the highest as the number of stages of weeding increased. The decreasing trend of NAR might be due to reduced photosynthetic activity during the later stages because of senescence of leaves. Weed infestation at vegetative growth stage significantly decreased NAR and concluded that to obtain maximum NAR, weeding should be extended across all growth stages, especially during the reproductive stage.

\section{Yield and yield components}

Results revealed that all yield and yield contributing characters were significantly influenced by weeding (Table 4). The highest number of pods plant ${ }^{-1}(22.03)$, mature pods plant ${ }^{-1}(15.22)$, pod length $(5.95 \mathrm{~cm})$, number of seeds pod $^{-1}(17.07)$, seed weight plant ${ }^{-1}(23.51 \mathrm{~g})$, 1000- seed weight $(39.71 \mathrm{~g})$, seed yield $\left(1.38 \mathrm{tha}^{-1}\right)$ and stover yield $\left(3.41 \mathrm{t} \mathrm{ha}^{-1}\right)$ were found in $\mathrm{T}_{7}$ (three stages weeding from Emergence to Maturity) and the lowest number of pods plant $^{-1}(12.15)$, mature pod plant ${ }^{-1}(9.21)$, pod length $(4.12 \mathrm{~cm})$, 
number of seeds $\operatorname{pod}^{-1}(9.99)$, seed weight plant $^{-1}(7.85 \mathrm{~g}), 1000$ - seed weight $(27.87 \mathrm{~g})$, seed yield $(0.91 \mathrm{t}$ $\mathrm{ha}^{-1}$ ) and stover yield $\left(1.76 \mathrm{t} \mathrm{ha}^{-1}\right)$ were found in $\mathrm{T}_{1}$ (no weeding treatment). The highest seed yield from $\mathrm{T}_{7}$ occurred due to increased number of pods plant ${ }^{-1}$, larger-number of seeds plant $^{-1}$ and the highest weight of individual seed. $T_{7}$ produced the highest yield might be due to maximum production of crop characters and influenced the plant to have good production of dry matter in early stage and that eventually raised and partitioned to the reproductive units. The weeding also helped optimum seed development. Lower assimilate production for inhibition of photosynthesis and less translocation toward the reproductive organ happened due to unweeded condition in $T_{1}$ and resulted in lower seed yield. This result was supported by Raman and Krishnamoorthy (2005). The biological yield and harvest index were found to vary under different weeding conditions. The highest biological yield $\left(4.70 \mathrm{t} \mathrm{ha}^{-1}\right)$ was obtained in plants from $\mathrm{T}_{6}$ (two stage weeding) and the lowest biological yield $\left(2.67 \mathrm{t} \mathrm{ha}^{-1}\right.$ ) was recorded from $\mathrm{T}_{1}$. The highest harvest index $(37.15 \%)$ was obtained from $\mathrm{T}_{4}$ (one-stage weeding treatment, $\mathrm{P}-\mathrm{M}$ ) and the lowest harvest index (30.85\%) was recorded from $\mathrm{T}_{7}$ (Table 4).

Table 4. Effect of weeding on yield and yield components of mungbean

\begin{tabular}{|c|c|c|c|c|c|c|c|c|c|c|}
\hline Treatment & $\begin{array}{l}\text { Pods plant }{ }^{-1} \\
\text { (no.) }\end{array}$ & $\begin{array}{c}\text { Mature pods } \\
\text { plant }^{-1} \text { (no.) }\end{array}$ & $\begin{array}{l}\text { Length of } \\
\operatorname{pod}(\mathrm{cm})\end{array}$ & $\begin{array}{l}\text { Seeds } \\
\text { pod }^{-1} \\
\text { (no.) }\end{array}$ & $\begin{array}{l}\text { Seed wt. } \\
\text { plant-1 } \\
(\mathrm{g})\end{array}$ & $\begin{array}{c}\text { 1000-seed } \\
\text { wt. (g) }\end{array}$ & \begin{tabular}{|c|} 
Seed yield \\
$\left(\mathrm{t} \mathrm{ha}^{-1}\right)$
\end{tabular} & $\begin{array}{l}\text { Stover } \\
\text { yield } \\
\left(\mathrm{t} \mathrm{ha}^{-1}\right)\end{array}$ & $\begin{array}{c}\text { Biological } \\
\text { Yield } \\
\left(\mathrm{t} \mathrm{ha}^{-1}\right)\end{array}$ & $\begin{array}{c}\text { Harvest } \\
\text { Index (\%) }\end{array}$ \\
\hline $\mathrm{T}_{1}$ & $12.15 \mathrm{e}$ & $9.21 f$ & $4.12 \mathrm{e}$ & $9.99 d$ & $7.85 f$ & $27.87 d$ & $0.91 \mathrm{e}$ & $1.76 \mathrm{~d}$ & $2.67 \mathrm{e}$ & $34.12 \mathrm{~b}$ \\
\hline $\mathrm{T}_{2}$ & $19.60 \mathrm{~b}$ & $13.89 \mathrm{~b}$ & $5.41 \mathrm{c}$ & $14.49 \mathrm{c}$ & $11.53 \mathrm{e}$ & $33.10 \mathrm{c}$ & $1.15 d$ & $2.30 c$ & $3.44 \mathrm{~cd}$ & $33.30 \mathrm{bc}$ \\
\hline$T_{3}$ & $17.16 \mathrm{~d}$ & 10.93de & $5.68 b$ & $14.20 \mathrm{c}$ & $14.64 \mathrm{c}$ & $38.10 \mathrm{ab}$ & $1.18 \mathrm{c}$ & $2.40 c$ & $3.59 c$ & $33.02 b c$ \\
\hline $\mathrm{T}_{4}$ & $18.35 \mathrm{c}$ & $11.32 \mathrm{~d}$ & $5.19 d$ & $14.55 \mathrm{c}$ & $13.37 \mathrm{~cd}$ & $34.09 \mathrm{c}$ & $1.19 \mathrm{c}$ & $2.01 \mathrm{C}$ & $3.19 d$ & $37.15 a$ \\
\hline$T_{5}$ & $18.02 \mathrm{C}$ & $11.86 \mathrm{c}$ & $5.26 \mathrm{~cd}$ & $16.05 b$ & $18.74 b$ & $37.70 \mathrm{~b}$ & $1.20 \mathrm{c}$ & 2.56 & $3.76 \mathrm{c}$ & $32.25 b c$ \\
\hline$T_{6}$ & $17.26 \mathrm{~d}$ & $10.53 e$ & $5.20 d$ & 16.60ab & $16.91 b$ & $38.24 a b$ & $1.29 b$ & $3.41 a b$ & $4.70 a$ & $27.51 d$ \\
\hline $\mathrm{T}_{7}$ & $22.03 a$ & $15.22 a$ & $5.95 a$ & $17.07 a$ & $23.51 a$ & $39.71 a$ & $1.38 \mathrm{a}$ & $3.09 a$ & $4.47 \mathrm{~b}$ & $30.85 c$ \\
\hline CV (\%) & 2.19 & 3.22 & 4.64 & 2.42 & 7.24 & 3.37 & 1.57 & 5.95 & 4.06 & 4.38 \\
\hline $\begin{array}{l}\text { Level of } \\
\text { sig. }\end{array}$ & ** & ** & ** & ** & ** & ** & $\star *$ & ** & ** & ** \\
\hline
\end{tabular}

In a column, figures with similar letter (s) or without letter do not differ significantly (as per DMRT) at $5 \%$ level of probability $* *=$ Significant at $1 \%$ level of probability.

Where, $T_{1}=$ no weeding, $T_{2}=$ one-stage weeding (Emergence-Flowering), $T_{3}=$ one-stage weeding (Flowering-Pod setting), $T_{4}=$ one-stage weeding (Pod setting-Maturity), $T_{5}=$ two-stage weeding (Emergence Flowering and Flowering-Pod setting), $T_{6}=$ twostage weeding (Flowering-Pod setting and Pod setting-Maturity) and $T_{7}=$ three-stage weeding (Emergence-Flowering and Flowering-Pod setting and Pod setting-Maturity).

\section{Correlation and Regression}

Correlation between yield per plant and other characters: The correlation coefficients between yield and chosen components traits are presented in (Table 5). Number of pods plant ${ }^{-1}$, number of seed pod ${ }^{-1}$ showed highly significant correlations ( 0.979 and 0.937 , respectively) with seed yield plant ${ }^{-1}$. The correlation among pod length and yield plant ${ }^{-1}$ was significantly positive $(0.845)$. The correlation among seed weight plant ${ }^{-1}$ and yield plant ${ }^{-1}$ was significantly positive $(0.877)$ and the correlation among $1000-$ seed weight and yield plant ${ }^{-1}$ was significantly positive (0.899). All other correlation with yield were also positive and but not strongly correlated with yield. All had positive and significant association with final grain yield of mungbean.

Table 5. Correlations matrix between yield and yield components

\begin{tabular}{|c|c|c|c|c|c|c|}
\hline Parameters & $\begin{array}{c}\text { Pods plant } \\
\text { (no.) }\end{array}$ & $\begin{array}{l}\text { Pod length } \\
(\mathrm{cm})\end{array}$ & $\begin{array}{c}\text { Seeds pod } \\
\text { (no.) }\end{array}$ & $\begin{array}{l}\text { Seed wt. } \\
\text { plant }^{-1}(g)\end{array}$ & $\begin{array}{c}\text { 1000-seed wt. } \\
(\mathrm{g})\end{array}$ & $\begin{array}{l}\text { Yield } \\
\text { plant }^{-1}\end{array}$ \\
\hline Pods plant $^{-1}$ (no.) & 1.000 & & & & & \\
\hline Pod length (cm) & $0.825(* \star)$ & 1.000 & & & & \\
\hline Seeds pod ${ }^{-1}$ (no.) & $\left.0.930^{(* *}\right)$ & $0.781(* \star)$ & 1.000 & & & \\
\hline Seed wt. plant ${ }^{-1}(\mathrm{~g})$ & $0.855(* *)$ & $0.706\left(^{\star \star}\right)$ & $0.867(* \star)$ & 1.000 & & \\
\hline 1000-seed wt. (g) & $0.839\left(^{* \star}\right)$ & $0.790\left(^{\star \star}\right)$ & $0.888(* \star)$ & $0.890\left(^{(\star \star}\right)$ & 1.000 & \\
\hline Yield plant $^{-1}$ & $0.979(* *)$ & $0.845\left(^{(* \star}\right)$ & $0.937\left(^{* \star}\right)$ & $\left.0.877^{(* *}\right)$ & $\left.0.899^{(* *}\right)$ & 1.000 \\
\hline
\end{tabular}

** Correlation is significant at the 0.01 level (2-tailed), * Correlation is significant at the 0.05 level (2- tailed) 


\section{R. Akter et al.}

The relation among number of pod plant ${ }^{-1}$, pod length, number of seed $\operatorname{pod}^{-1}, 1000$ - seed weight and yield were positive and linear $\left(R^{2}=0.958, R^{2}=0.714, R^{2}=0.877\right.$ and $R^{2}=0.807$, respectively) (Fig. 2, Fig. 3, Fig. 4 and Fig. 5, respectively).

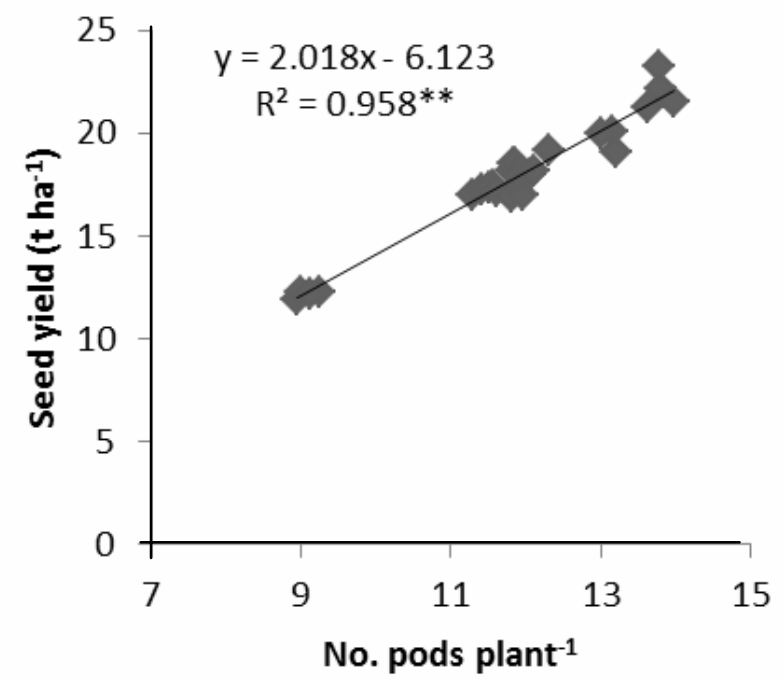

Fig. 2. Regression of no. of pods plant ${ }^{-1}$ on seed yield of mungbean

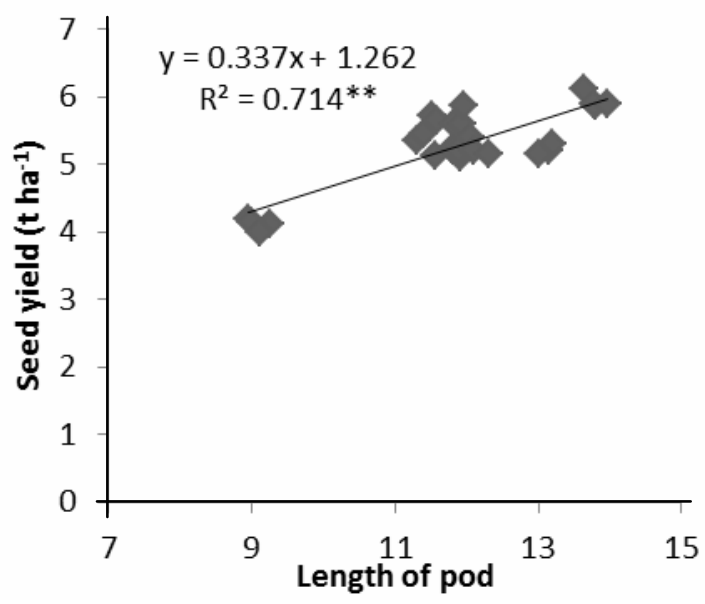

Fig. 3. Regression of length of pod on seed yield of mungbean

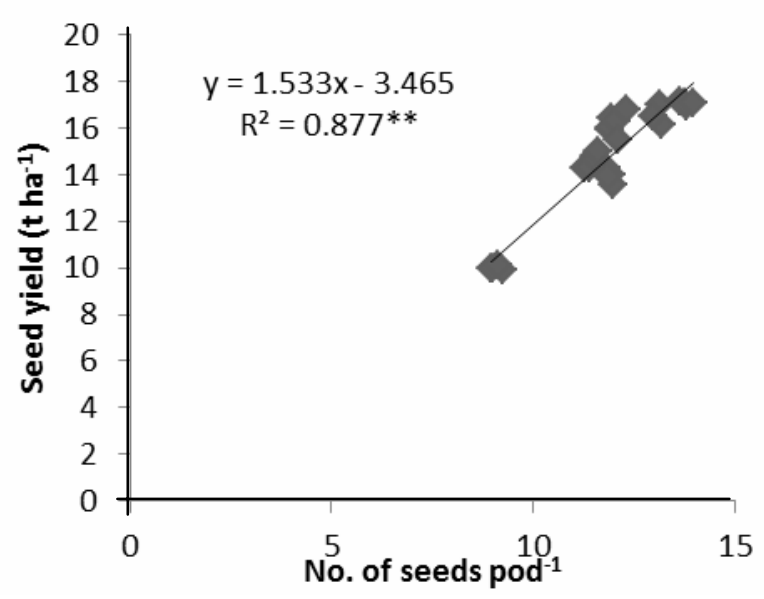

Fig. 4. Regression of no. of seed pod $^{-1}$ on seed yield of mungbean 


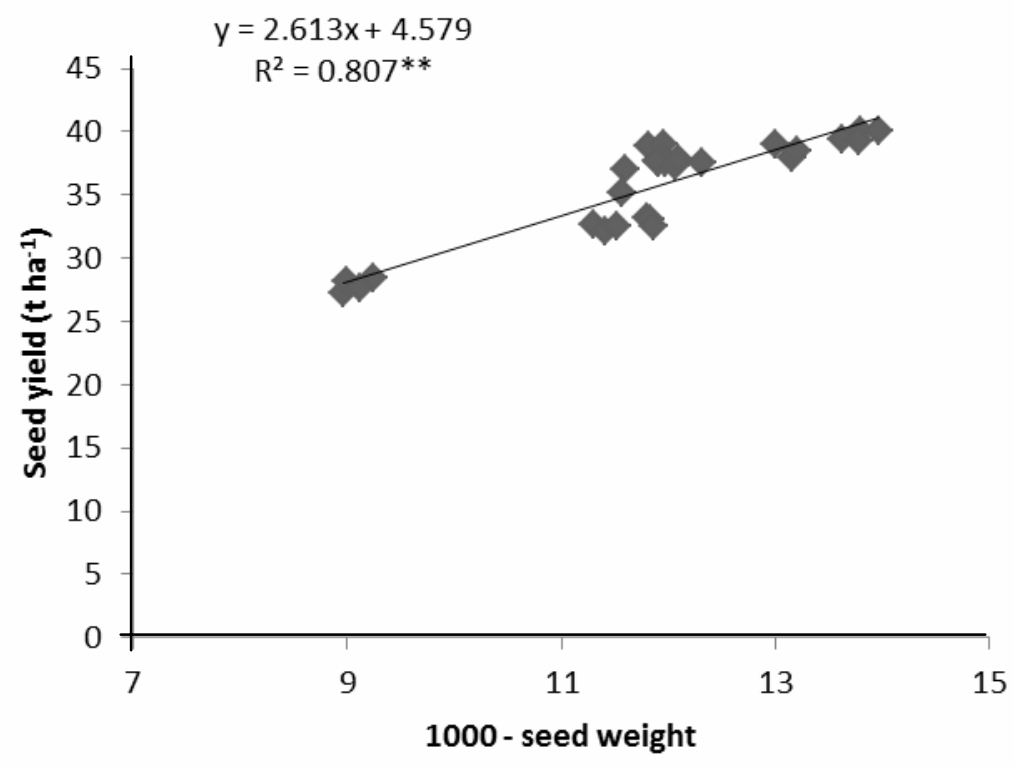

Fig. 5. Regression of 1000-seed weight on seed yield of mungbean

\section{Conclusion}

From the above results, it may be concluded that BINA mung- 4 gave maximum yield at three-stage weeding in the three different growth stages like emergence to flowering (E-M), flowering to pod setting (F-P) and pod setting to maturity (P-M).

\section{References}

Afzal, M.A., Murshad, A.N.M.M.M., Bakar, M.A., Hamid, A. and Salahuddin A.B.M. 2008. Mungbean Cultivation in Bangladesh. Gazipur, Bangladesh: Pulse Research Station, Bangladesh Agricultural Research Institute.

BBS (Bangladesh Bureau of Statistics). 2008. Monthly Statistical Pocket Book of Bangladesh, Minis. Plan., Govt. People's Repub. Bangladesh, Dhaka. p. 372.

BBS (Bangladesh Bureau of Statistics). 2011. Statistical Yearbook of Bangladesh. Stat. Div., Minis. Plan., Govt. People's Repub. Bangladesh, Dhaka. p. 37.

BINA (Bangladesh Institute of Nuclear Agriculture). 2011. Annual Report of Bangladesh Inst. Nuc. Agric. for the year 2010-2011. P. O. Box No. 4. Mymensingh.

Bueren, E.T.L., Struik, P.C. and Jacobsen, E. 2002. Ecological concepts in organic farming and their consequences for an organic crop ideotype. J. Life Sci. 50: 1-26.

Gomez, K.A. and Gomez, A.A. 1984. Statistical Procedures for Agricultural Research. $2^{\text {nd }}$ edn. John Wiley and Sons, New York. pp. 207-215.

Hossain, M.A., Karim, M.F. and Maniruzzaman, A.F.M. 1990. Response of summer mungbean to levels of field management. Appl. Agric. Res. 5: 289-92.

Hunt, R. 1978. Plant Growth Analysis. London: Edward Pub. Ltd. p. 67.

Islam, M.A., Mamun, A.A., Bhuiyan, M.S.U. and Hossain, S.M.A. 1989. Weed biomass and grain yield in wheat as affected by seed rate and duration of weed competition. Bangladesh J. Agril. Sci. 14: 213-224.

Kumar, S. and Kiron, M. S. 1990. Studies on crop weed competition in summer mungbean. Legume Res. 13:110-120.

Musa, M., Chawdhury, G.A., Khalid, A.H., Shahzad, M.A. and Cheema, N.M. 1996. Weed competition studies in mungbean. Absts. $5^{\text {th }}$. Pakistan Weeds Sci. Conf. March 3-5.

Pandey, J. and Mishra, B.N. 2003. Effect of weed management practices in a rice mustard-mungbean cropping system on weeds and yield of crops. Annals Agric. Res. 24: 737-742.

Raman, R. and Krishnamoorthy, R. 2005. Nodulation and yield of mungbean (Vigna radiata L.) influenced by integrated weed management practices. Legume Res. 28: 128-130. 